\title{
Fungistatic activity of essential oils towards selected oilseed rape pathogens
}

\author{
Właściwości fungistatyczne olejków eterycznych \\ wobec wybranych patogenów rzepaku
}

\author{
Romuald Gwiazdowski ${ }^{1 *}$, Daniela Gwiazdowska², Katarzyna Marchwińska², Krzysztof Juś ${ }^{2}$, \\ Julia Szutowska², Amelia Bednarek-Bartsch ${ }^{1}$, Beata Danielewicz ${ }^{1}$
}

\section{Summary}

Essential oils are complex, volatile compounds of plants origin, mainly obtained by steam distillation or extraction of the plant parts, i.e. seeds, leaves, fruits, bark or roots. These compounds exhibit a broad biological activity e.g. antimicrobial including fungistatic effect. The aim of the presented work was to determine the antifungal activity of 20 essential oils against chosen fungi: Alternaria alternata, Alternaria brassicicola, Botrytis cinerea and Sclerotinia sclerotiorum. The tests performed in 96-well microtiter plates were set up to define the minimum inhibitory concentration. Based on the obtained results it can be concluded that the tested essential oils exhibit antifungal activity towards examined filamentous fungi, however the MIC (Minimal Inhibitory Concentration) value was differentiated depending on the essential oil and fungal species. The lowest MIC values were obtained for lemon, grapefruit, cinnamon and oregano essential oils.

Key words: oilseed rape; pathogenic fungi; essential oils

\section{Streszczenie}

Olejki eteryczne to złożone, lotne związki pochodzenia roślinnego, otrzymywane głównie poprzez destylację parową lub ekstrakcję części roślin, tj. nasion, liści, owoców, kory czy korzeni. Związki te wykazują szeroką aktywność biologiczną m.in. przeciwdrobnoustrojową, w tym fungistatyczną. Celem badań było określenie aktywności fungistatycznej 20 olejków eterycznych wobec Alternaria alternata, Alternaria brassicicola, Botrytis cinerea oraz Sclerotinia sclerotiorum. Badania przeprowadzono na 96-dołkowych mikropłytkach, wyznaczając minimalne stężenie hamujące wzrost grzybów. Na podstawie uzyskanych wyników można stwierdzić, że testowane olejki eteryczne wykazują właściwości fungistatyczne względem badanych grzybów strzępkowych, jednakże wartość MIC zależy od olejku eterycznego i gatunku grzyba. Najniższe wartości MIC (Minimal Inhibitory Concentration - minimalne stężenie hamujące) uzyskano dla olejków: cytrynowego, grejpfrutowego, cynamonowego oraz lebiodkowego.

Słowa kluczowe: rzepak; grzyby patogeniczne; olejki eteryczne

\footnotetext{
${ }^{1}$ Instytut Ochrony Roślin - Państwowy Instytut Badawczy

Władysława Węgorka 20, 60-318 Poznań

${ }^{2}$ Uniwersytet Ekonomiczny w Poznaniu

Wydział Towaroznawstwa, Katedra Przyrodniczych Podstaw Jakości

Al. Niepodległości 10, 61-875 Poznań

*corresponding author: r.gwiazdowski@iorpib.poznan.pl
} 


\section{Wstęp / Introduction}

Rzepak należy do najpowszechniej uprawianych roślin oleistych na świecie (Carré i Pouzet 2014), którego roczna produkcja nasion przekracza $50 \mathrm{mln}$ ton (USDA, GOV 2016). W Unii Europejskiej rzepak zajmuje ponad 80\% w strukturze uprawy roślin oleistych, natomiast w Polsce udział ten wynosi ponad 90\%, czyniąc nasz kraj jednym z największych w Europie producentów rzepaku i produktów z niego wytworzonych (Rosiak 2012). Biorąc pod uwagę istotny udział rzepaku w gospodarce rolnej, ważne jest by uzyskiwać jak najwyższe i cechujące się wysoką jakością plony. Jednym z największych zagrożeń upraw rzepaku są patogeniczne grzyby strzępkowe, które mogą przyczyniać się do powstania wielu chorób, co w sposób znaczący może wpłynąć na końcowe efekty uprawy (Gwiazdowski 2016). Do najczęściej występujących chorób rzepaku należy zaliczyć: suchą zgniliznę kapustnych (Leptosphaeria spp. st. kon. Phoma lingam), czerń krzyżowych (Alternaria spp.), zgniliznę twardzikową (Sclerotinia sclerotiorum) czy szarą pleśń (Botryotinia fuckeliana st. kon. Botrytis cinera). Niektóre mikroorganizmy, takie jak: Pythium debaryanum, Rhizoctonia solani, Alternaria spp. i Fusarium spp. mogą powodować zgorzele siewek i hamować rozwój roślin, natomiast grzyby rodzaju Verticillium czy gatunek Plasmodiophora brassicae przyczyniają się do powstania chorób płodozmianowych, takich jak werticilioza i kiła kapusty (Mrówczyński i wsp. 2009). Patogeny rzepaku mogą występować w ciągu całego okresu jego wegetacji, infekując w różnym zakresie wszystkie organy roślinne (Mączyńska i Krzyzińska 2000). Porażenie rzepaku przez grzyby może mieć zmienne nasilenie w zależności od różnego rodzaju czynników zarówno abiotycznych (np. ogólna suma i rozkład opadów, temperatura i wilgotność względna powietrza) czy biologicznych (m.in. odmiana rzepaku, gatunek patogena, obecność szkodników). Istotnym czynnikiem jest również odpowiednio dobrana technika agrotechniczna, która może wpłynąć na poprawę zdrowotności rzepaku (Mrówczyński i wsp. 2009).

Próba ograniczenia strat powodowanych przez patogeniczne grzyby, a jednocześnie wyraźne tendencje zmierzające do stosowania niechemicznych metod ochrony roślin, skłaniają do poszukiwania nowych substancji ograniczających rozwój grzybów. Stąd coraz większe zainteresowanie substancjami pochodzenia naturalnego, do których należą olejki eteryczne.

Olejki eteryczne to naturalne i lotne związki chemiczne charakteryzujące się silnym zapachem, wytwarzane przez różne części roślin jako ich wtórne metabolity (Burt 2004). Pozyskiwane są m.in. z kwiatów, owoców, nasion, liści, korzeni, a także z kory i kłączy (Bakkali i wsp. 2008; Molski 2009). Olejki eteryczne są to mieszaniny wielu związków chemicznych, zawierające od 20 do 60 składników w różnych zakresach stężeń. Zwykle w ich składzie dominują dwa bądź trzy związki chemiczne (od 20 do 70\%), warunkujące właściwości olejków eterycznych (Bakkali i wsp. 2008), podczas gdy pozostałe komponenty występują w śladowych ilościach. Skład chemiczny oraz właściwości olejków eterycznych mogą się zmieniać w zależności od czasu i miejsca zbioru roślin oraz metody ich pozyskiwania (Molski 2009). Zainteresowanie tymi substancjami jest związane przede wszystkim z ich aktywnością biologiczną, która stwarza szerokie możliwości zastosowania. Jak wskazują dane literaturowe, olejki eteryczne działają antybakteryjnie, przeciwwirusowo oraz fungistatycznie (Burt 2004; Bakkali i wsp. 2008; Lv i wsp. 2011). Potencjał przeciwgrzybowy olejków eterycznych jest coraz częściej badany, zarówno wobec grzybów występujących w żywności, jak też stanowiących problem w medycynie czy rolnictwie.

Celem niniejszej pracy było określenie aktywności komercyjnych olejków eterycznych wobec wybranych patogenów rzepaku.

\section{Materiały i metody / Materials and methods}

Materiał badawczy stanowiło 20 komercyjnych olejków eterycznych: z ziela mięty zielonej (Mentha spicata, Chiny), z liści mięty pieprzowej (Mentha piperita, Indie), z korzenia imbiru (Zingiber officinale, Chiny), z igieł jodły (Abies sibirica, Syberia), z ziela lebiodki (Origanum vulgare, kraje śródziemnomorskie), z nasion kopru włoskiego (Foeniculum vulgare var. dulce, Rosja/Bułgaria), z kory jałowca wirgilijskiego (Juniperus virginiana, USA), z żywicy drzewa balsamowca mirra (Commiphora myrrha, Somalia), z kory drzewa cynamonowego (Cinnamonum zeylanicum, Indonezja), z liści drzewa cynamonowego (Cinnamonum zeylanicum, Indonezja), z owoców pomarańczy bergamotki (Citrus aurantium var. bergamia, Włochy), z kwiatów ylang ylang (Cananga odorata, Madagaskar), z liści i kwiatów werbeny (Thymus hiemalis, Hiszpania), ze skórki grejpfruta białego (Citrus grandis, Włochy), ze skórki grejpfruta różowego (Citrus paradisi, Argentyna), ze skórki cytryny (Citrus limonum, Włochy), ze skórki limy (Citrus aurantifolia, Indie Zachodnie), ze skórki pomarańczy (Citrus aurantium var. dulcis, Brazylia), petitgrain z liści drzewa pomarańczowego (Citrus aurantium, Hiszpania) oraz z nasion marchwi (Daucus carota, Wielka Brytania). Olejki eteryczne zakupione zostały na rynku krajowym.

Jako mikroorganizmy wskaźnikowe wybrano cztery grzyby z gatunków: Alternaria alternata KZF 13, Alternaria brassicicola BPR 1893, B. cinerea BPR 187 i S. sclerotiorum KZF 23. Szczepy pochodziły z kolekcji Zakładu Badania Środków Ochrony Roślin oraz Banku Patogenów Roślin i Badania ich Bioróżnorodności Instytutu Ochrony Roślin - Państwowego Instytutu Badawczego w Poznaniu.

Ocenę aktywności fungistatycznej przeprowadzono metodą dwukrotnych rozcieńczeń z wykorzystaniem 96-doł- 
kowych mikropłytek titracyjnych, wyznaczając minimalne stężenie hamujące MIC (Minimal Inhibitory Concentration). Olejki eteryczne przygotowano w postaci roztworów $\left(10 \mathrm{mg} / \mathrm{cm}^{3}\right) \mathrm{w}$ sterylnej wodzie destylowanej $\mathrm{z}$ dodatkiem Tween 80 (10\%). Na płytce titracyjnej wykonano dwukrotne rozcieńczenia przygotowanych olejków w bulionie PDB (Potato Dextrose Broth, BIOSHOP), uzyskując ostateczny zakres stężeń olejków eterycznych od 0,04 do $5 \mathrm{mg} / \mathrm{cm}^{3}$. Następnie wprowadzano zawiesiny zarodników do PDB, otrzymane z 7-10-dniowych hodowli grzybów rosnących wcześniej na podłożu PDA (Potato Dextrose Agar, BIOSHOP). Liczebność zarodników w zawiesinie, określona $\mathrm{w}$ hemocytometrze, wynosiła $10^{4} \mathrm{jtk} / \mathrm{cm}^{3}$. Inkubację prowadzono przez 7-10 dni w temperaturze pokojowej (około $20^{\circ} \mathrm{C}$ ), w warunkach tlenowych. W przypadku grzyba $S$. sclerotiorum grzybnię z płytki PDA przenoszono do PDB, dokładnie mieszano na vortexie i ustalano gę- stość optyczną tak przygotowanej zawiesiny na poziomie 1,0 w skali MacFarlanda. Po zakończeniu inkubacji dokonywano wizualnego odczytu wyników, obserwując wzrost grzybów w poszczególnych studzienkach. Jako wartość MIC przyjmowano najniższe stężenie olejku, które hamowało wzrost grzyba. Badania prowadzono w trzech powtórzeniach.

\section{Wyniki i dyskusja / Results and discussion}

Wyniki doświadczeń prezentujące wartości MIC wyznaczone dla badanych olejków eterycznych zamieszczono w tabeli 1. Jak wynika $\mathrm{z}$ danych, większość olejków eterycznych wykazywała aktywność fungistatyczną względem badanych grzybów, przy czym wartości MIC różniły się w zależności od gatunku grzyba oraz rodzaju olejku.

Tabela 1. Oddziaływanie olejków eterycznych przeciw badanym grzybom

Table 1. The influence of essential oils towards the tested fungi

\begin{tabular}{|c|c|c|c|c|}
\hline \multirow{2}{*}{$\begin{array}{l}\text { Olejek z } \\
\text { Essential oil from }\end{array}$} & \multicolumn{4}{|c|}{$\begin{array}{c}\text { Minimalne stężenie hamujące wzrost wybranych grzybów } \\
\text { Minimal concentration inhibiting the growth of selected fungi } \\
\qquad\left[\mathrm{mg} / \mathrm{cm}^{3}\right]\end{array}$} \\
\hline & $\begin{array}{l}\text { Alternaria } \\
\text { alternata }\end{array}$ & $\begin{array}{c}\text { Alternaria } \\
\text { brassicicola }\end{array}$ & $\begin{array}{l}\text { Botrytis } \\
\text { cinerea }\end{array}$ & $\begin{array}{l}\text { Sclerotinia } \\
\text { sclerotiorum }\end{array}$ \\
\hline Ziela mięty zielonej - Spearmint herb & 0,62 & 0,62 & 0,31 & 0,62 \\
\hline Liści mięty pieprzowej - Peppermint leaves & 1,25 & 0,62 & 0,31 & 0,08 \\
\hline Korzenia imbiru - Ginger root & $>5,00$ & 1,25 & 5,00 & 0,31 \\
\hline Igieł jodły - Fir needles & 2,50 & 5,00 & $>5,00$ & $\leq 0,04$ \\
\hline Ziela lebiodki - Oregano herb & $\leq 0,04$ & $\leq 0,04$ & $\leq 0,04$ & $\leq 0,04$ \\
\hline Nasion kopru włoskiego - Fennel seeds & $\leq 0,04$ & $\leq 0,04$ & 0,16 & $\leq 0,04$ \\
\hline Kory jałowca wirgilijskiego - Cedarwood bark & $>5,00$ & $>5,00$ & $>5,00$ & 2,50 \\
\hline Żywicy drzewa mirra - Resin tree myrrh & 5,00 & 5,00 & $>5,00$ & 5,00 \\
\hline Kory drzewa cynamonowego - Cinnamon tree bark & $\leq 0,04$ & $\leq 0,04$ & $\leq 0,04$ & $\leq 0,04$ \\
\hline Liści drzewa cynamonowego - Cinnamon tree leaves & $\leq 0,04$ & $\leq 0,04$ & $\leq 0,04$ & $\leq 0,04$ \\
\hline Owoców bergamotki - Bergamot fruit & 2,50 & 0,31 & 1,25 & $\leq 0,04$ \\
\hline Kwiatów ylang ylang - Ylang ylang fowers & 0,31 & 0,08 & 0,62 & $\leq 0,04$ \\
\hline Liści i kwiatów werbeny - Verbena leaves and flowers & 0,08 & 0,08 & 0,16 & $\leq 0,04$ \\
\hline Skórki grejpfruta białego - White grapefruit peel & $>5,00$ & 1,25 & $>5,00$ & 1,25 \\
\hline Skórki grejpfruta różowego - Pink grapefruit peel & $>5,00$ & 1,25 & $>5,00$ & 0,08 \\
\hline Skórki cytryny - Lemon peel & $>5,00$ & 1,25 & $>5,00$ & $\leq 0,04$ \\
\hline Skórki limetki - Lime peel & 5,00 & 1,25 & 5,00 & $\leq 0,04$ \\
\hline Skórki pomarańczy - Orange peel & $>5,00$ & $>5,00$ & $>5,00$ & 0,08 \\
\hline $\begin{array}{l}\text { Petitgrain z liści drzewa pomarańczowego } \\
\text { Petitgrain from orange tree leaves }\end{array}$ & 2,50 & 0,16 & 1,25 & $\leq 0,04$ \\
\hline Nasion marchwi - Carrot seeds & $>5,00$ & $>5,00$ & $>5,00$ & $\leq 0,04$ \\
\hline
\end{tabular}


Najsilniejsze działanie hamujące wzrost grzybów wykazały olejki: lebiodkowy, cynamonowy z kory i z liści, z kopru włoskiego oraz werbeny. Trzy pierwsze olejki hamowały wzrost wszystkich badanych grzybów w stężeniu $\leq 0,04 \mathrm{mg} / \mathrm{cm}^{3}$. Równie silne właściwości fungistatyczne wykazywał olejek z kopru włoskiego w stosunku do grzybów A. alternata, A. brassicicola i S. sclerotiorum, natomiast względem $B$. cinerea wartość MIC wynosiła $0,16 \mathrm{mg} / \mathrm{cm}^{3}$. Olejek z werbeny wykazywał najsilniejsze działanie wobec grzyba S. sclerotiorum, gdzie wartość MIC wynosiła $0,04 \mathrm{mg} / \mathrm{cm}^{3}$, natomiast w stosunku do pozostałych grzybów wartość MIC kształtowała się na wyższym poziomie: $0,08 \mathrm{mg} / \mathrm{cm}^{3}$ wobec $A$. alternata i $A$. brassicicola oraz $0,16 \mathrm{mg} / \mathrm{cm}^{3}$ wobec $B$. cinerea. Silne działanie fungistatyczne wykazywały olejki ylang ylang, olejki z mięty zielonej i pieprzowej, w przypadku których wartość MIC kształtowała się w zakresie od $\leq 0,04$ do $1,25 \mathrm{mg} / \mathrm{cm}^{3}$, $\mathrm{w}$ zależności od gatunku grzyba. $\mathrm{Z}$ kolei olejki petitgrain oraz bergamotkowy silnie hamowały wzrost $A$. brassicicola i $S$. sclerotiorum (MIC na poziomie $\leq 0,04$ do $0,31 \mathrm{mg} / \mathrm{cm}^{3}$ ), a w stosunku do pozostałych grzybów wartość MIC była wyższa i sięgała do $2,5 \mathrm{mg} / \mathrm{cm}^{3}$. Pozostałe olejki wykazywały bardziej zróżnicowane i zdecydowanie słabsze oddziaływanie względem badanych gatunków grzybów. Najsłabsze właściwości fungistatyczne w badanym zakresie stężeń wykazały olejki z jałowca wirgilijskiego i nasion marchwi. W przypadku obu tych olejków eterycznych nie zaobserwowano zahamowania wzrostu grzybów A. alternata, $A$. brassicicola i $B$. cinerea w badanym zakresie stężeń, chociaż wykazywały silne hamowanie wzrostu S. sclerotium $\left(\mathrm{MIC} \leq 0,04 \mathrm{mg} / \mathrm{cm}^{3}\right)$.

Uzyskane wyniki wskazują, że wrażliwość badanych grzybów na działanie poszczególnych olejków eterycznych była zróżnicowana. Na rysunku 1. przedstawiono procento- we zestawienie olejków eterycznych działających w określonym zakresie na dany gatunek grzyba. Jako kryterium podziału przyjęto wartości MIC równe 1 oraz $5 \mathrm{mg} / \mathrm{cm}^{3}$. Największą wrażliwość na działanie olejków eterycznych wykazywał grzyb S. sclerotiorum, którego wzrost był hamowany przez 17 testowanych olejków już w niskim stężeniu. Dużą wrażliwość na działanie olejków eterycznych wykazał również gatunek $A$. brassicicola. Połowa testowanych olejków hamowała wzrost tego grzyba w niskim stężeniu $\left(\mathrm{MIC}<1 \mathrm{mg} / \mathrm{cm}^{3}\right)$, a 35\% olejków działała aktywnie w zakresie stężeń $1-5 \mathrm{mg} / \mathrm{cm}^{3}$. Z kolei najmniejszą wrażliwość wykazały grzyby $A$. alternata i $B$. cinerea, w stosunku do których, odpowiednio 35 i 40\% badanych olejków eterycznych nie oddziaływało w badanym zakresie stężeń.

Uzyskane rezultaty potwierdzają dane literaturowe, wskazujące na fungistatyczne oddziaływanie olejków eterycznych. Warto przy tym podkreślić duże zróżnicowanie aktywności biologicznej tych związków względem grzybów, na co wskazują zarówno dane literaturowe, jak i wyniki prezentowanej pracy. Seseni i wsp. (2015) wykazali zróżnicowane oddziaływanie 10 olejków eterycznych wobec grzybów z rodzaju Fusarium (F. oxysporum i $F$. circinatum), przy czym najsilniejsze właściwości fungistatyczne posiadały olejki: z goździków, tymianku i trawy cytrynowej. Wartość MIC dla tych olejków kształtowała się na poziomie 300-500 $\mu \mathrm{l} / \mathrm{cm}^{3}$, w zależności od olejku i gatunku grzyba. Z kolei najsłabszą aktywność w stosunku do badanych grzybów wykazały olejki: z mandarynek, grapefruita i pomarańczy. Rezultaty te są zgodne z uzyskanymi w niniejszej pracy, gdzie olejek z grapefruita i pomarańczy należały do olejków o najsłabszym działaniu fungistatycznym. Khaledi i wsp. (2014) badali oddziaływanie olejków eterycznych z mięty, kminku czarnego i tymianku na wzrost grzybów $R$. solani i Macrophomina phaseolina, będących patoge-

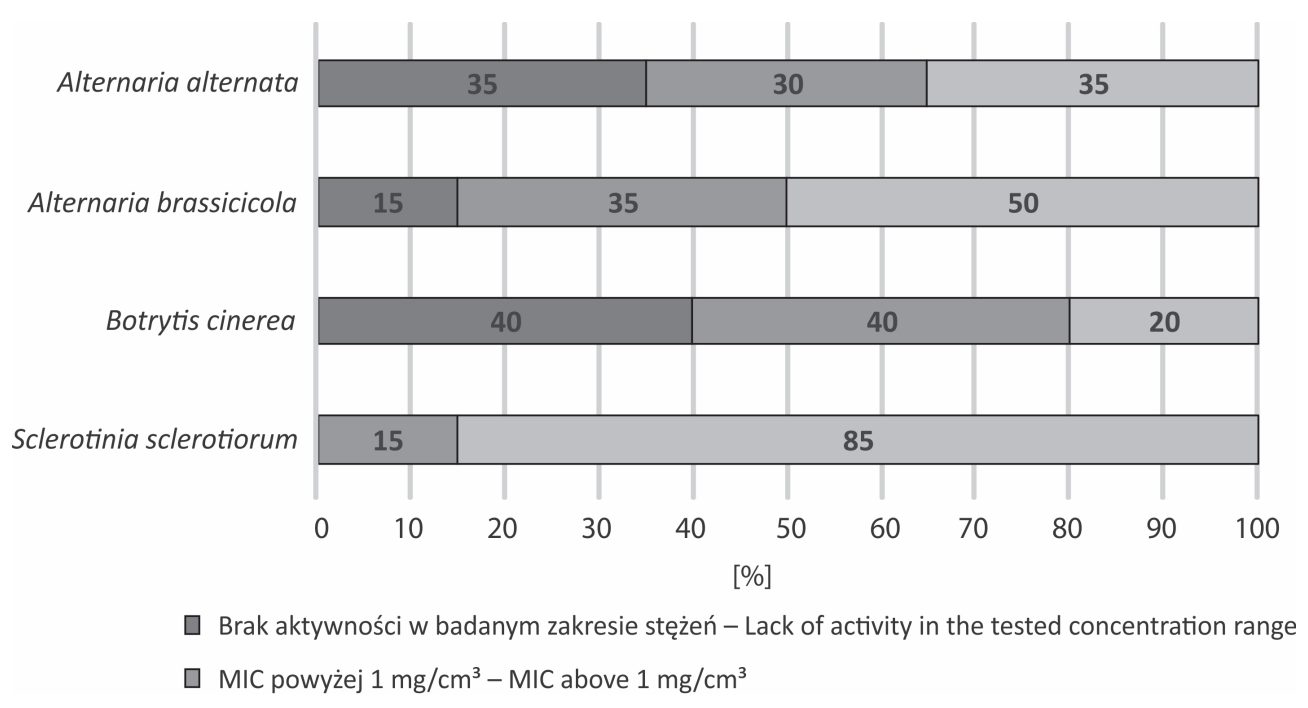

Rys. 1. Procent olejków eterycznych wykazujących określoną aktywność względem badanych grzybów

Fig. 1. Percentage of essential oils exhibiting specific activity towards tested fungi 
nami fasoli. Najniższe wartości MIC autorzy uzyskali dla olejku z mięty pieprzowej. W prezentowanej pracy olejki z mięty również należały do grupy silnie hamujących wzrost testowanych grzybów. W badaniach Soylu i wsp. (2010) całkowite zahamowanie wzrostu $B$. cinerea przez olejek z oregano uzyskano przy stężeniu $0,2 \mu \mathrm{g} / \mathrm{cm}^{3}$, podczas gdy olejki z lawendy i rozmarynu wykazywały taką aktywność W stężeniu 1,6 $\mu \mathrm{g} / \mathrm{cm}^{3}$. Podobnie, Bouchra i wsp. (2003) wykazali silne oddziaływanie olejków z oregano (Origanum compactum) i macierzanki (Thymus glandulosus) wobec B. cinerea, przy czym jako główne składniki hamujące rozwój grzybni wskazali tymol oraz karwakol.

Dane literaturowe wskazują, że olejki eteryczne mogą uszkadzać grzybnię, chociaż dokładny mechanizm ich działania na komórki grzybów nie został w pełni wyjaśniony. Obserwacje mikroskopowe przeprowadzone przez Fiori i wsp. (2000), Romagnoli i wsp. (2005), Soylu i wsp. (2005, 2006, 2010) wykazywały zdeformowane strzępki, zmniejszone średnice strzępek, jak również lizę ściany komórkowej po potraktowaniu grzybów olejkiem eterycznym. Uważa się, że takie modyfikacje mogą być związane z zaburzeniem syntezy ściany komórkowej (Rasooli i wsp. 2006). Ze względu na lipofilową budowę substancji zapachowych, olejki eteryczne mogą przenikać przez ścianę komórkową i błonę cytoplazmatyczną powodując zakłócenia w funkcjonowaniu kwasów tłuszczowych, polisacharydów czy fosfolipidów. Zniszczenia struktury ściany komórkowej i cytoplazmy prowadzą do przepuszczania makrocząsteczek do środowiska zewnętrznego, czego rezultatem jest liza komórki (Bakkali i wsp. 2008).
Ze względu na liczne właściwości olejków eterycznych, są one coraz częściej wykorzystywane w przemyśle kosmetycznym, farmaceutycznym, spożywczym, w medycynie (Bakkali i wsp. 2008), jak również w rolnictwie. Biorąc pod uwagę fakt, że w uprawie roślin kładzie się obecnie nacisk na integrowaną ochronę $\mathrm{z}$ uwzględnieniem metod niechemicznych, mogą one stanowić alternatywę dla fungicydów. Ponadto, najnowsze badania dowodzą, że olejki eteryczne charakteryzują się nie tylko aktywnością fungistatyczną, ale w warunkach in vitro wykazują także zdolność degradacji mykotoksyn (Perczak i wsp. 2016), co z praktycznego punktu widzenia jest cenną właściwością.

\section{Wnioski / Conclusions}

1. W warunkach laboratoryjnych wszystkie testowane olejki eteryczne hamowały wzrost wybranych grzybów strzępkowych w różnym zakresie stężeń.

2. Najsilniejsze właściwości fungistatyczne wykazały olejki: lebiodkowy, cynamonowy z kory i z liści, z kopru włoskiego i werbeny, dla których wyznaczono najniższe wartości MIC.

3. Najsłabsze właściwości fungistatyczne wykazały olejki eteryczne pozyskane z nasion marchwi i kory cedru.

4. Najbardziej wrażliwym spośród 4 analizowanych izolatów był $S$. sclerotiorum, którego wzrost był hamowany przez 13 spośród 20 olejków eterycznych w stężeniu $0,04 \mathrm{mg} / \mathrm{cm}^{3}$.

\section{Literatura / References}

Bakkali F., Averbeck S., Averbeck D., Idaomar M. 2008. Biological effects of essential oils - a review. Food and Chemical Toxicology 46 (2): 446-475. DOI: 10.1016/j.fct.2007.09.106.

Bouchra C., Achouri M., Idrissi Hassani L.M., Hmamouchi M. 2003. Chemical composition and antifungal activity of essential oils of seven Moroccan Labiatae against Botrytis cinerea Pers: Fr. Journal of Ethnopharmacology 89 (1): 165-169. DOI: 10.1016/S03788741(03)00275-7.

Burt S. 2004. Essential oils: their antibacterial properties and potential applications in foods - a review. International Journal of Food Microbiology 94 (3): 223-253. DOI: 10.1016/j.ijfoodmicro.2004.03.022.

Carré P., Pouzet A. 2014. Rapeseed market, worldwide and in Europe. OCL 21 (1), D102, 12 pp. DOI: 10.1051/ocl/2013054.

Fiori A.C.G., Schwan-Estrada K.R.F., Stangarlin J.R., Vida J.B., Scapim C.A., Cruz M.E.S., Pascholati S.F. 2000. Antifungal activity of leaf extracts and essential oils of some medicinal plants against Didymella bryoniae. Journal of Phytopathology 148 (7-8): $483-487$. DOI: $10.1046 / j .1439-0434.2000 .00524 . x$.

Gwiazdowski R. 2016. Ocena możliwości zastosowania bakterii Propionibacterium freudenreichii ssp. shermanii P4 oraz Lactobacillus plantarum L2 w ochronie rzepaku ozimego przed chorobami. Rozprawy Naukowe Instytutu Ochrony Roślin Państwowego Instytutu Badawczego, Zeszyt 31, 124 ss.

Khaledi N., Taheri P., Tarighi S. 2014. Antifungal activity of various essential oils against Rhizoctonia solani and Macrophomina phaseolina as major bean pathogens. Journal of Applied Microbiology 118 (3): 704-717. DOI: 10.1111/jam.12730.

Lv F., Liang H., Yuan Q., Li C. 2011. In vitro antimicrobial effects and mechanism of action of selected plant essential oil combinations againt four food-related microorganisms. Food Research International 44 (9): 3057-3064. DOI: 10.1016/j.foodres.2011.07.030.

Mączyńska A., Krzyzińska B. 2000. Wpływ fungicydu Horizon 250 EW na zdrowotność, rozwój i plon rzepaku ozimego. [Influence of Horizon $250 \mathrm{EW}$ on health, development and yield of winter oilseed rape]. Rośliny Oleiste - Oilseed Crops 21 (1): 105-112.

Molski M. 2009. Chemia piękna. Wydanie II. Wydawnictwo Naukowe PWN, Warszawa, 420 ss. ISBN 978-83-0115-71-42.

Mrówczyński M., Korbas M., Praczyk T., Gwiazdowski R., Jajor E., Pruszyński G., Wachowiak H. 2009. Ochrona roślin w integrowanej produkcji rzepaku. [Plant protection in integrated oilseed rape production]. Rośliny Oleiste - Oilseed Crops 30 (2): 245-256. 
Perczak A., Juś K., Marchwińska K., Gwiazdowska D., Waśkiewicz A., Goliński P. 2016. Degradation of zearalenone by essential oils under in vitro conditions. Frontiers in Microbiology 7: 1224. DOI: 10.3389/fmicb.2016.01224.

Rasooli I., Rezaei M.B., Allameh A. 2006. Growth inhibition and morphological alterations of Aspergillus niger by essential oils from Thymus eriocalyx and Thymus x-porlock. Food Control 17 (5): 359-364. DOI: 10.1016/j.foodcont.2004.12.002.

Romagnoli C., Bruni R., Andreotti E., Rai M.K., Vicentini C.B., Mares D. 2005. Chemical characterization and antifungal activity of essential oil of capitula from wild Indian Tagetes patula L. Protoplasma 225 (1-2): 57-65. DOI: 10.1007/s00709-005-0084-8.

Rosiak E. 2012. Stan i perspektywy rynku rzepaku w Polsce na tle rynku światowego. [Situation and outlook rapseed market of according to world market]. Roczniki Naukowe Stowarzyszenia Ekonomistów Rolnictwa i Agrobiznesu 14 (1): 417-422.

Seseni L., Regnier T., Roux-van der Merwe M.P., Mogale E., Badenhorst J. 2015. Control of Fusarium spp. causing damping-off of pine seedlings by means of selected essential oils. Industrial Crops and Products 76: 329-332. DOI: 10.1016/j.indcrop.2015.07.002

Soylu E.M., Kurt Ş., Soylu S. 2010. In vitro and in vivo antifungal activities of the essential oils of various plants against tomato grey mould disease agent Botrytis cinerea. International Journal of Food Microbiology 143 (3): 183-189. DOI: 10.1016/j.ijfoodmicro 2010.08.015.

Soylu E.M., Soylu S., Kurt S. 2006. Antimicrobial activities of the essential oils of various plants against tomato late blight disease agent Phytophthora infestans. Mycopathologia 161 (2): 119-128. DOI: 10.1007/s11046-005-0206-z.

Soylu E.M., Yiğitbaş H., Tok F.M., Soylu S., Kurt S., Baysal Ö., Kaya A.D. 2005. Chemical composition and antifungal activity of the essential oil of Artemisia annua L. against foliar and soil-borne fungal pathogens. Journal of Plant Diseases and Protection 112 (3): $229-239$.

USDA, GOV. 2016. http://www.fas.usda.gov [dostęp: luty 2018]. 